\title{
Psciendo
}

\author{
Bram Wauters, Gilles Pittoors \\ Research group GASPAR (Ghent University), Belgium
}

\section{POPULIST PARTY LEADERS IN BELGIUM: AN ANALYSIS OF VB AND PVDA-PTB}

DOI: $10.2478 /$ ppsr-2019-0001

\begin{abstract}
Authors
Bram Wauters is an associate professor at the Department of Political Sciences of Ghent University, where he leads the research group GASPAR. He teaches a number of introductory and specialized courses in the master and bachelor programmes 'Public Management and Public Policy' and 'Political Science'. His research interests include political representation, elections and political parties, with special attention for diversity. He has recently published on these topics in journals such as Party Politics, Political Studies, Political Research Quarterly, and Politics \& Gender.
\end{abstract}

ORCID no. 0000-0003-4216-2094

e-mail: bram.wauters@ugent.be

Gilles Pittoors is a PhD candidate and teaching assistant at the Ghent Association for the Study of Parties and Representation (GASPAR) of Ghent University. He studied history and European politics at KU Leuven. His research focuses on the functioning of parties and democracy in multi-level systems. Before starting in academia, he worked at the European Commission and for Brussels-based advocacy groups.

ORCID no. 0000-0002-0433-3203

\begin{abstract}
This article scrutinizes the position and the role of the party leader in two populist parties in Belgium: Vlaams Belang (VB) and Partij van de Arbeid - Parti du Travail de Belgique (PVDA-PTB). Following Mudde's definition, populism is understood as a people-centered and anti-elitist ideology. The article argues that, if one accepts the notion that parties will organize themselves in line with their ideological beliefs, then one should expect populist parties to exhibit three main characteristics: leaders are directly elected by the party members, they have extensive powers with only minimal intra-party institutional checks, and they feature strongly in electoral campaigns. Applying this argument to the two Belgian populist parties, the article finds only limited evidence for the argument that populist parties mirror their ideology in the role and position of their party leader.
\end{abstract}

Keywords: populism, populist parties, Belgium, party leaders, leadership selection

\section{Introduction}

Over the past decades, populism and populist parties have become increasingly important, both politically and academically. Politically, there are an increasing number of populist parties that have obtained electoral victories, participate in government and/or lend support to minority governments. In France, the Front National (FN) under the leadership of Marine Le Pen became a serious contender in the presidential elections with realistic 
chances of winning these elections. In Austria, the radical-right populist FPÖ has joined the government, while in Italy, the Lega Nord not only achieved a massive electoral victory, but its leader Matteo Salvini is considered the strongman of the current Italian government. In Poland and Hungary respectively, Kaczynski and Orban-both considered almost archetypical populist leaders - have near-total control of the state and government.

Also academically, research on populism has surged over the past two decades. A large chunk of this research concerns the electoral performance and campaign styles of populist parties (Akkerman, Mudde, \& Zaslove, 2013; Barr, Clarke, \& Lewis, 2018; Canovan, 1999; R. Heinisch, 2003; Mudde, 2013, 2014; Pauwels, 2011a, 2015; Webb, 2013; Zaslove, 2008). However, these studies have often suffered from conceptual problems, as there was simultaneously a large debate on how to define populism and populist parties (de Vreese, Esser, Aalberg, Reinemann, \& Stanyer, 2018; Jagers \& Walgrave, 2007; Moffitt \& Tormey, 2013; Mudde, 2004, 2008; Pauwels, 2011a; Rooduijn \& Pauwels, 2011; Viviani, 2017; Weyland, 2001; Wiles, 1969). This conceptual debate was more or less settled by Cas Mudde, whose widely accepted definition of populism understands it as a thin-centered ideology "that considers society to be ultimately separated into two homogeneous and antagonistic groups, 'the pure people' versus 'the corrupt elite', and which argues that politics should be an expression of the volonté générale (general will) of the people" (Mudde, 2004, p. 543). This definition also forms the basis of this article.

The organization of these parties has so far been a less crowded topic (Reinhard Heinisch \& Mazzoleni, 2016; McDonnell, 2017; Van Haute \& Pauwels, 2016). Particularly the position of the party leader within the organization remains unclear. There seems to be a popular image of populist parties that stand and fall with a charismatic leader who has total control of the party organization (Reinhard Heinisch \& Mazzoleni, 2016). Nonetheless, recent research has questioned this image, arguing that populist leaders are not necessarily the sole defenders of the people their parties depict them to be (McDonnell, 2015, 2017; Viviani, 2017). This article therefore aims to further examine the position of populist party leaders.

In general terms, we expect a link between a party's ideology and its organization. Enyedi and Linek (2008) give three reasons for this link: direct ideological effects; indirect social background influences; and historical origins. It is argued that, if populist parties were to apply their views on democracy onto their own party organization, this would lead to a party in which the leader is directly elected by the members, is the main strongman of the party in electoral campaigns and, once in power, has extensive powers with only little institutional checks and balances to consider.

We focus on Belgium, which might provide an atypical case in cross-country perspective, as all parties there have a strong party leader with extended powers and they all allow party members to directly elect the party leader. It is interesting to see how populist parties position themselves in terms of organization towards these 'populist' practices: do they follow some of the principles adopted by other parties, or do they distinguish themselves from established parties?

The article starts by defining populist parties and delineating populist parties in the Belgian context, ending up with two Belgian parties that can be catalogued as populist parties, namely Vlaams Belang (VB) and Partij van de Arbeid - Parti du Travail de Belgique (PVDA-PTB). For these two parties, we investigate four indictors of their party leaders: their 
formal powers according to the statutory rules, how they are selected (both according to the formal rules and in practice), their career pattern and their electoral performance. The article finds that VB and PVDA-PTB do not meet our expectations based on populist ideology. Not only are their leaders not directly elected, they are not always the prime electoral spearheads and have to share power with other authoritative actors within their parties.

\section{Defining populism and populist parties}

Although research on populism and populist parties stretches back to the 1960s (Wiles, 1969), it has been inflicted with the chronic lack of a unified definition of its meaning. Indeed, Wiles' observation that a researcher's definition of populism differs "according to the academic axe he grinds" is still relevant today, almost half a century later (McDonnell, 2017; Wiles, 1969, p. 166). Both in academic and public debates, populism has variably been used to refer to an ideology, a political style, a type of political mobilization or a popular movement (for a broader discussion, see: Taggart, 2000; Viviani, 2017). Nonetheless, in the past few years there has emerged somewhat of a consensus around the definition put forward by Cas Mudde. He claims that populism is a thin-centered ideology "that considers society to be ultimately separated into two homogeneous and antagonistic groups, 'the pure people' versus 'the corrupt elite', and which argues that politics should be an expression of the volonté générale (general will) of the people" (Mudde, 2004, p. 543). Populism thus has a thin, but highly moralistic view of society, centered around the normative and absolute distinction between a good/pure people and an evil/corrupt elite. As such, populism can easily be identified with other, more fleshed-out ideologies such as nationalism or socialism.

Still, while this definition more or less settles the discussion on the fundamental nature of the beast, it does not provide clear indicators that can be used to delineate populist parties. In line with Mudde's definition, Rooduijn et al. $(2015 ; 2012)$ argue that populism is mostly about the message rather than about the actor. This populist message, so they claim, is defined by two elements: people-centrism and anti-elitism. The former, however, is a rather vague concept. For one, who exactly 'the people' are that populists defend is highly unclear and tends to differ depending on who one asks. Taggart (1998) and Mudde (2004) have compared the populists' 'people' to the nationalists' 'nation', as both are imaginary and idealized (Van Haute, Pauwels, \& Sinardet, 2018). In any case, populists claim to defend the people and fight whatever prevents the people's will from being put into policies - be it political opposition, minority protection or institutional checks and balances. The vox populi in its purest and unfiltered form should thus be the guiding principle for all political action.

This connects to the second element of the populist message: anti-elitism. This anti-elite message is often much more clear and coherent than the pro-people message, as it is directed at concrete institutions, organizations or even individuals. Although the populist message can target all kinds of elites - from cultural to intellectual and economical, or even judicial - it is most often directed at the political elite (Rooduijn et al., 2012). Indeed, "what European populists have in common is a rejection of the cartel-like power of entrenched political elites" (Jones, 2007, p. 38). They argue that the political establishment "corrupt[s] the link between leaders and supporters, create[s] artificial divisions within the homogeneous people, and put[s] their own interests above those of the people" (Mud- 
de, 2004, p. 546). Hence they claim to differ from the political establishment and take on the role of a political outsider who defends the people against the malpractices of the corrupt elites.

Essentially, populists thus claim to represent the voxpopuli. All political decisions should be a direct expression of this will of the people, but this is obstructed by intermediaries, most notably by a corrupt political establishment, who intervene in the direct relationship between people and leaders. However, by focusing on the message rather than the actor, Rooduijn et al. $(2015 ; 2012)$ imply that populism is a spectrum rather than a black or white dichotomy. The difference between parties thus comes down to the extent to which they make use of a populist discourse. At one end of this continuum would be those parties that make systemic use of the populist message, constantly claiming to represent the voice of the people oppressed by a corrupt elite. At the other end of the continuum are parties who only occasionally-particularly, one would assume, during election time-make use of such populist phrasings.

Most parties that have been dubbed 'populist' can be found on the more radical sides of the political spectrum. Rejecting the status quo and the ruling establishment is a common feature of both populist and radical political tendencies (for a broader debate on these concepts see: Carter, 2018; Mudde, 2014). Yet, most research on populist and radical parties is focused almost exclusively on the right-wing side of the political spectrum - which was put in the spotlight most notably by Mudde's work on the populist radical-right (Mudde, 2007). However, in studying over 30 parties in Western European countries, Rooduijn et al. have shown that "radical parties on both the left and the right are inclined to employ a populist discourse" (2015, p. 193).

\section{Populist parties and party leaders}

Now we focus on the leaders of populist parties and ask ourselves how this function would be carried out in this kind of party. Enyedi and Linek (2008) give three reasons for a link between a party's ideology and a party's organization: direct ideological effects; indirect social background influences; and historical origins. We are here, in particular, interested in direct ideological effects. This refers to parties applying their ideological views to the way their party is organized. For instance, if a party is in favor of direct democracy, it is likely that they will also apply this principle to their own party organization by giving the rank and file a large say in the internal functioning of the party (Close, 2018). The social composition of their followers (attracting a large, well-organized group has different organizational consequences than a smaller, wealthy group) and historical decisions (path-dependency) also could have an impact, but they seem to be less relevant for populist parties who were only quite recently established and/or gaining success. Although other variables (e.g. on the country level) also have an impact, Enyedi and Linek (2008) found that centre-right parties in Central and Eastern Europe had a organizational pattern clearly different from leftist parties, including fewer staff members, a simpler structure, a more personalized style of leadership with a more important role in public office.

In line with populist ideology - that the will of the 'good' people is absolute and that 'corrupt' elites attempt to thwart this will-it can be expected that populist parties will promote a direct connection between the people and policy with as little distortion as possible. In practice, this results in demands for more direct democracy, and consequently 
a close link between the people and political leadership, eliminating distortion by mid-level elites. At first glance, populist parties seem to practice what they preach. Indeed, for as long as they exist, populist parties have the reputation of being led by charismatic leaders whose personal popularity determines, to a large extent, the popularity of the party. For example, the success of the French Front National (now: Rassemblement National) is strongly connected with the personal popularity of its leader, Marine Le Pen. The same goes for other parties such as the Hungarian Fidesz en the Dutch Freedom Party, both of whom revolve around their respective strongmen Orbàn and Wilders. Also the Italian Five Star Movement started off as the personal fan club of political comedian, Beppe Grillo.

Indeed, the populist political message is embodied by "the image of [the party leader as] an outsider and the plebiscitary bond between leader and voters" (Viviani, 2017, p. 288). As argued by Taggart, "populism celebrates the ordinariness of its constituents and the extraordinariness of their leaders" (2000, p. 102). Populist leaders "cast themselves as the saviors of the people, fighting to save their prosperity, values and sovereignty from the hands of uncaring rapacious elites" (McDonnell, 2017, p. 28). Several scholars even claim that having a charismatic leader is a cornerstone of populism and populist parties (Canovan, 1999; de Lange \& Art, 2011; McDonnell, 2015; Weyland, 2001; Zaslove, 2008). As such, the image arises of populist parties that stand and fall with their charismatic leaders who have total control of the party organization (Reinhard Heinisch \& Mazzoleni, 2016).

However, recent research has debunked at least two of those claims. For one, Mudde has argued that "the current success of populist actors cannot be separated from the general trend towards strong party leaders and more direct communication between party leadership and party supporters" (2004, p. 545). Indeed, the personalization of politics is a more general trend that can be observed in all kinds of parties (Karvonen, 2010) - although it is very common indeed among populist parties (Viviani, 2017). McDonnell $(2015,2017)$ goes further and not only argues that populist leaders do not always meet the established criteria for being 'charismatic', but also that many populist parties have (albeit not without some effort) survived and even thrived after a change in leadership. The most notable examples include Salvini's Lega Nord and Le Pen's FN.

Still, the roles that these leaders take in the internal organization of the party remains ambiguous and understudied. Although populist leaders might indeed be put forward as 'saviors of the people', research is unclear about whether or not populist leaders rule their party with an iron fist, and whether they internally promote the same direct democratic principles they want the state to implement. For example, Heinisch and Mazzoleni (2016) present a comprehensive study of the organization of populist parties, but explicitly do not address the particular position of the party leader. If one expects that populist parties internally walk the talk, then one can put forward three very clear expectations regarding leaders in populist parties: (1) they will be directly elected by the party members without much interference from intermediaries; (2) formal power and authority is consequently concentrated in their own office, by bypassing mid-level party elites; and (3) they will hence also play a central role in parties' electoral campaign strategies. The central position of the party leader as the party's main power hub, both formally and informally, is thus a direct consequence of the populist ideal of people-empowerment and the elimination of 'distorting' mid-level elites. This would be consistent with their discourse on the immediate implementation of the vox populi by an authoritative leadership figure, as argued extensively by Norris and Inglehart (2019). 
These aspects of populist parties - the centralization of power in the hands of the leader, internal direct democracy and focused electoral campaigns and results - will be studied more closely for the two Belgian populist parties: VB and PVDA-PTB. To study these elements, the article investigates four indicators of their party leaders. First, the article delves into leaders' formal powers according to the statutory rules. Second, the article assesses how leaders are selected, both according to the formal rules in the statutes and in practice. Third and fourth, the career patterns and electoral performance of the current and former party leaders are assessed, giving an indication of their role in campaigns and the concentration of power in their hands.

Data is gathered from the party's statutory rules and from public information, which are the main sources of data. In addition, two interviews were conducted with officials from PVDA-PTB because the communist party's statutes were at times limited or unclear. These interviews, however, serve not as a prime data source but rather as clarification of the party statutes. Additionally, the article differentiates between the formal and informal aspects of the party leader's role by contrasting what is written in the statutory rules with an analysis of the historical development of the party based on public information. For example, it contrasts how leaders ought to be selected according to the statutory rules versus how they have been in the past. Moreover, their formal statutory powers are contrasted with the more informal aspects of their internal position, such as their electoral results and career patterns. Nevertheless, we are aware that by using publicly available information only part of all informal aspects can be revealed.

\section{Case selection: populist parties in Belgium}

Based on these fundamental characteristics of populism, the question arises which Belgian parties can be labeled populist. Belgian parties do occasionally utter some populist phrases, but not all can be identified as populist parties pur sang. The Flemish socialists (sp.a) in the late 1990s and early 2000s, for example, regularly used a populist discourse-even calling for a "left-wing populism with foundations" (Mudde, 2004, p. 551) - without, therefore, rejecting altogether the Belgian/Flemish political establishment. Moving further to the right side of the political spectrum, the Flemish nationalists (N-VA) regularly make use of a discourse that attacks elites, including the judiciary, and present themselves as outsiders and alternatives to the political establishment. However, while the party is clearly nationalist and regularly attacks the 'Belgian' establishment, it does not go as far as to claim that there is a homogenous and corrupt elite (Pauwels, 2011b).

As in many other countries, therefore, populist parties in Belgium can be found mostly at the radical edges of the political spectrum, both the left and the right. These are the radical-right Vlaams Belang (VB) and the radical-left Partij van de Arbeid-Parti du Travail de Belgique (PVDA-PTB). Although there are numerous examples of politicians and parties who make use of a populist narrative and discourse to a greater or lesser degree, VB and PVDA-PTB do this to more extensively and hence are closest to the general understanding of populist parties. Indeed, they fundamentally pitch the people versus the corrupt elite, present both as largely homogenous and want to see policy as the unfiltered expression of the will of the people. Whilst in the past decades scholarly attention was directed almost exclusively at the radical-right VB (de Lange \& Mügge, 2015; Jagers \& Walgrave, 2007; Mudde, 2007, 2013, 2014; Pauwels, 2015), more recently research also 
takes into account the radical-left PVDA-PTB (Barr et al., 2018; Pauwels, 2011a; Rooduijn \& Akkerman, 2015). Perhaps also other (smaller) parties in Belgium can be catalogued as 'populist' (including the Parti Populaire and the Front National), but we decided here to restrict our analysis to the two largest and most relevant populist parties, for which information is more widely available.

The selection of VB and PVDA-PTB conforms with both the real-life discourse of both parties and the most (recent) research on populist parties in Belgium and the Low Countries. For one, VB's party statutes clearly say that the state and its institutions are inferior to the "popular community". The PVDA-PTB, similarly, systematically hammers on about how the ordinary people are being abused by a corrupt elite - bankers, traders, multinationals and politicians alike. Their current program opens with a reference to "those who govern us", accusing them of "robbing us of our right to decide on policies".

VB (or Vlaams Belang) is a radical-right, Flemish separatist party. The party was founded in 2004 as the heir to Vlaams Blok, which in turn was founded in 1978 after a split from the more centrist Flemish nationalist Volksunie. Although the party originally strongly emphasized Flemish independence, their focus gradually shifted towards anti-immigration, which has become their core business for decades now. VB saw its big breakthrough in the federal elections of 1991, where it captured almost 7\% of the votes ${ }^{1}$ - in Belgium these elections became known as 'black Sunday'. As a reaction, all other Belgian parties issued a cordon sanitaire against the VB stating that they would not collaborate on any policy level with that party. Nonetheless, VB would continue to grow throughout the 1990s, gaining its biggest electoral victory in the 2003 federal elections, when it captured almost $12 \%$ of the vote. However, in 2004 the party was convicted of promoting a racist agenda. This forced the leadership to create a new party or otherwise they would risk losing their public funding: Vlaams Belang (VB) was born. That year they attained their last big electoral victory, gaining $24 \%$ in the Flemish elections of 2004. After that, however, they quickly fell back. In the 2014 federal election, VB only received $3.7 \%$ of the vote. However, recent polls indicate again a slight growth for VB.

The PVDA-PTB has a much more humble electoral history. It was founded in the late 1970s as the political heir to the AMADA movement-Alle Macht Aan De Arbeiders (all power to the workers) - which was a revolutionary Marxist movement led by Ludo Martens. This took place in a broader softening of the revolutionary character of the party, allowing for participation in bourgeois elections and cooperation with other communist parties and movements. However, excepting some local successes - such as the local elections in Zelzate, where the party managed to capture almost $22 \%$ of votes in 2006 - the party only attained its first national representatives in the 2014 elections. Before 2014, it hardly managed to gain more than $1 \%$ of the votes. Its 2014 results were not overwhelming, capturing only $3.7 \%$ of the votes, but a few local successes in the provinces of Liège and Hainaut provided the party with two representatives in the House. Since then, however, particularly in the Walloon region, the PVDA-PTB has surged in the polls, polling around $16 \%$ and becoming the third largest party in the region. Also in Flanders PVDA-PTB is expected to reach in some districts the electoral threshold of $5 \%$ in the next national elections.

1 Although 7\% might not seem a monstrous amount, VB only participated in elections at the Flemish side of the country, making its electoral gains in those districts highly significant. Its total seats in the federal House increased from 2 to 10 . 
Before we start our analysis of populist party leaders, we first have to make clear the status and position of a party leader in Belgium. A party leader in Belgian parties can simply be defined as the one who is formally empowered as such by the party statutes. This formal party president (or party chairman) is generally considered to be the party leader in Belgian parties (Deschouwer, 2009; Pilet \& Wauters, 2014). His functions are extended and include everyday management of the party, coordinating party activities, being the figurehead of the party in election campaigns, taking the final decisions on policy stances, selecting candidates for parliamentary and ministerial offices and being the party's primary spokesperson in the media. Unlike in Westminster System countries, his function does not coincide with that of leader of the parliamentary party (de Vet \& Wauters, 2018). The party leader is in general also not the leader of the party in government: most Belgian parties apply an incompatibility rule between the position of party president and member of a government. When party leaders become a minister, they resign from their position as party president (Pilet \& Wauters, 2014). The party leader is also not necessarily the electoral leader, i.e. the spearhead of the party in the election campaign. This could be, for instance, the (deputy) prime minister, who is normally not the party chairman. Although all Belgian party leaders are central figures in their respective parties, their formal powers as laid down in the party statutes and their real powers might differ significantly. As indicated above, we will now investigate four elements of the VB and PVDA-PTB party leaders: their formal powers according to the statutory rules, how they are selected, their career pattern and their electoral performance.

Taking into account the strong position of the party leader in Belgium's partitocracy and the observation that party leaders are, in almost all parties, directly elected by the members (see also below) (Deschouwer, 2009), it seems that Belgian parties in general already possess some features associated with populism. In this sense, Belgium might provide an atypical case in a cross-country perspective. The way populist parties themselves organize in terms of leadership could then go in one of two directions. On the one hand, they could adopt the same type of plebiscitary democracy as the other Belgian parties. This would be in line with their populist ideology and it also likely that parties mimic (successful) practices of other parties in the same country (or region in this case) (Chiru, Gauja, Gherghina, \& Rodriguez-Teruel, 2015; Poguntke, Scarrow, \& Webb, 2016). On the other hand, populist parties like to differentiate themselves from established parties. They do not want to be associated with this 'corrupt elite' who neglects the will of the people. Therefore, it could also be expected that they want to distinguish themselves from established parties by organizing differently.

\section{Formal powers of party leaders}

We investigate now the formal powers of party leaders in VB and PVDA-PTB. We do this by looking at the powers attributed to them in the party statutes.

$V B$

Belgium is known as a partitocracy (De Winter \& Dumont, 2000; Dewachter, 2005, 2014), which means that political life is dominated by parties and party leaders. It should thus come as no surprise that most parties attribute some importance to the function of party 
leader. However, and especially compared to other Flemish parties, the party statutes of VB bestow a lot of formal power on the party leader.

The importance of the party leader is, first of all, demonstrated by the amount of text attributed to this position in the VB-statutes: of a document of little over 12 pages, more than a full page is dedicated to the party leader. By comparison, the statutes of the Flemish Christian-democrats (CD\&V) also dedicate about one page, but out of a document of 74 pages.

The VB statutes explicitly give the leader not only the basic powers that party leaders in most Flemish parties have - such as responsibility for the general organization and management of the party, and ex officio presidency of the party executive - but adds a series of additional powers (Table 1). These include being the first spokesperson of the party, both in the media and in a court of law; the sole power of sanctioning and excluding party members (although the party council can challenge this); and, most importantly, the power to appoint members of the party executive (although approval of the party council is needed). With most other Belgian parties, these different functions and powers are divided between different organs within the party. For example, according to the formal rules of the Flemish socialist party (sp.a), relations with the media is the prime responsibility of the national secretariat, issuing sanctions is in the hands of a specific disciplinary committee, while members of the party executive are elected by the party congress.

In fact, in all other Belgian parties the members of the party executive are either ex officio members or elected by the party assembly or party council. The VB party executive, however, consists of the party president and vice-president, the leaders of the different parliamentary groups, the treasurer and the president of the VB youth wing. Considering that the party leader has the power to appoint all these functions personally, combined with his other prerogatives, this puts the main source of formal power in the party in his or her hands. As such, from a formal perspective, "if the overall structure of the VB looks like that of other party organizations in Belgium, the formal distribution of roles as described in the party statutes is different and points towards a greater centralization of power" (Van Haute \& Pauwels, 2016, p. 72).

Table 1. Formal powers of party leaders in the Flemish parties as described in party statutes

\begin{tabular}{|l|c|c|c|c|c|c|c|}
\hline & VB & $\begin{array}{c}\text { PV- } \\
\text { DA-PTB }\end{array}$ & CD\&V & OVLD & N-VA & sp.a & Groen \\
\hline $\begin{array}{l}\text { general management of } \\
\text { the party }\end{array}$ & $\times$ & & $\times$ & $\times$ & $\times$ & $\times$ & $\times$ \\
\hline party spokesperson & $\times$ & & $\times$ & & & & \\
\hline $\begin{array}{l}\text { appointment of party } \\
\text { executives }\end{array}$ & $\times$ & & & & & & \\
\hline $\begin{array}{l}\text { ex officio president of the } \\
\text { party executive }\end{array}$ & $\times$ & $\times$ & $\times$ & $\times$ & $\times$ & $\times$ & \\
\hline legal representative & $\times$ & & & & & & \\
\hline $\begin{array}{l}\text { sanction and/or exclude } \\
\text { party members }\end{array}$ & $\times$ & & & & & & \\
\hline chairs the party congress & & & $\times$ & $\times$ & & & \\
\hline
\end{tabular}


In short, VB's party formal statutes are in line with the expectations regarding populist parties, meaning leadership by a single authoritative figure.

However, practice shows (see also below) that in reality VB is not led by a single person, but that leadership roles are divided among a small group of the party elite (increasingly so since the 1990s). In contrast to the populist discourse of strong leadership, the party president of the VB still has to fight for his power with other authoritative and influential people within the party. Still, it is clear that any obstruction to the leader's power is not of an institutional nature - there is no formal party organ described in the statutes that can realistically oppose the leader. The battle for power is between strong individuals, rather than between the leader and party institutions. VB thus partly falls in line with the populist rhetoric: it functions are based on authoritative individuals (although more than one) who are largely unbound by institutional checks and balances.

\section{PVDA-PTB}

If the VB statutes are explicit in the power that is attributed to the party leader, the PVDA-PTB statutes are remarkably vague. In fact, there is only one paragraph dedicated to the position of the party president. Article 31 says that the president chairs the national council, that the statutory conference "entrusts" the mandate of the president to the national council, and that the national council can depose the president. Beyond this, the statutes go deep into the power of the national council, but not at all into the concrete role of the party leader. Powers usually attributed to the party leader-including the general leadership and management of the party-are instead attributed to the national council (which is chaired by the party leader).

Article 36.1 further stipulates that in between council meetings, which take place at least once every three months, the party bureau takes over the leadership of the party. In turn, the party bureau is prepared by the party executive - the president, vice-president and the national secretary, in addition to any number of other members as required and allowed by the council. All these organs report directly to the national council-in short, the national council is the "sovereign institution" of the party (Delwit, 2014, p. 272, own translation).

It would thus seem that the formal powers within the PVDA-PTB rest with the national council, rather than with the office of the party president. There are no organs that are able to oppose decisions made by the national council, as all are either appointed or can be overruled by the council. Moreover, the outgoing council decides on both the criteria that define who is eligible to vote in the statutory congress, and the topics that will be discussed at the congress. Whoever controls the national council, thus controls the entire party.

The statutes are unclear, however, about how decisions are made inside the national council and what is the position of the party leader. The council consists of about 40 people, who are all elected by the statutory conference and which meets to discuss big party issues ranging from organizational reform to electoral positions. Thus it is not a small group from the party elite, making it unlikely to be dominated by the president. The fact that the party president chairs the national council is the only indication in the direction of a certain centralization of power with the party leader. 
Still, the absence of clear processes and role descriptions of the party president and other functions leaves ample room for party leadership discretion. Indeed, our conversations with the PVDA-PTB confirm that, in reality, the party executive (and more particularly the president, vice-president and national secretary of the executive) has a rather firm grip on the national council and hence on the party as a whole. True, the statutes say that the party executive is accountable to the bureau and the council-but both of these institutions are formed around the executive who also chairs them. As such, no real institutional barriers to their influence are provided.

It is clear that it is not the party president alone who controls the party, but rather the triumvirate of the party executive (including also the vice-president and national secretary). In fact, the balance of power between the members of the executive was arranged as such specifically in order to prevent the concentration of power with one person. Our interviews reveal that when the previous party leader - Ludo Martens - resigned in 2008, there was a general frustration within the party concerning his sole influence over the party (see also: Delwit, 2014).

For that reason, concurrent with a rejuvenation of the party and the change of leadership, the power of the president was divided between the three members of the executive. Yet power still resides with a small group of people, whose discretion is significant given the absence of clear procedures in the party statutes. This situation would more or less correspond with the populist view on society: controlling the party's central decision-making body, the party leadership enjoys the required discretion to lead in a decisive and authoritative way without interference from other institutional bodies. As with VB, while this power was initially concentrated in the hands of one person, it now resides with a small group of the party elite. As such, we can state that over time the leaders of these parties have become less strong (and hence functioned less according to 'populist ideas') when it comes to the formal powers.

\section{Selection of party leaders}

A second indicator we discuss is the way party leaders are selected in VB and PVDA-PTB. The distinction made by Poguntke et al. (2016) between assembly-based and plebiscitary forms of intra-party democracy is highly relevant in this perspective. Although both forms involve rank and file members in the selection of the party leader, the former does it in an indirect way by bringing together party members (or more often: party delegates) to deliberate and eventually decide, while the latter asks individual members to cast a vote directly. Clearly, the plebiscitary form is more in line with populist ideas, as it provides a direct link between the leader and the rank and file.

Almost all Belgian parties have evolved from an assembly-based system in which party delegates selected the party president, to a plebiscitary system in which all members are allowed to vote (Pilet \& Wauters, 2014). Initially, after WW II, party leaders were selected by party congresses that were composed of delegates of the regional (or even local) sections of the party. Rank and file members at the regional or local level selected delegates to represent them at a national party conference, which decided on the party leader. As such, this procedure can be situated somewhere in between the selection by a small group of the party elite and selection by all of the party members (Rahat \& Hazan, 2001). This procedure was gradually democratized especially during the course of the 1990s (Pilet \& 
Wauters, 2014) and now in almost all parties, party members select the party leader in direct elections. It comes then as no surprise that in a cross-national perspective, Belgian parties score high on the plebiscitary intra-party democracy index developed by Poguntke et al. (2016). The first major breakthrough of VB in 1991 (and the accompanying perceived 'gap' between citizens and politics) is often cited as one of the reasons for this democratization (Wauters, 2014). It is then perhaps no coincidence that VB did not take part in this evolution towards a plebiscitary party leadership selection.

$V B$

For a long time, there was no involvement at all of rank and file members and mid-level elites in the selection of the party leader of VB. Karel Dillen, who founded the party in 1978, was 'party leader for life'. When he voluntarily decided to resign in 1996, he alone decided who would be his successor. This is an example of a very exclusive selectorate, effectively only one person (Hazan \& Rahat, 2010). This is in sharp contrast with other Belgian parties, most of whom at that time already had membership elections to select their party leader. Dillen's successor Frank Van Hecke remained in office until 2008. With respectively 18 and 12 years in party office, Dillen and Van Hecke served much longer than the average party leader of Belgian parties, who in general keeps this function for only 4.8 years (Pilet \& Wauters, 2014).

Due to, amongst others, the critique that they were not functioning democratically (Jagers, 2002), the party decided to reform the formal procedure to select the party leader (Pilet \& Cross, 2018). This happened in 2004: it was decided that the party council would decide the party leader, and that the party conference would have to approve this choice. As such, it is now the party council that holds a vote. This party council consists of about 80 members and is composed of delegates of regional party sections and office-holders of the party (including MPs). The preferred candidate is subsequently confirmed by a party conference in which a larger part of the membership can participate. The statutory composition of this party conference was changed in 2012: whereas before it consisted of all elected MPs and all local councilors of the party, as well as all members of the executive board of all local party sections, now all members (who have been a member for at least one year) are entitled to participate. The formal procedure now resembles to a large extent an assembly-based procedure, which is comparable to what all established Belgian parties did before the reforms in the 1990s.

The steps towards democratization, however, have been very prudent in VB: in practice neither rank and file members nor voters are directly involved in the (first major phase of the) selection process. Up to now, three party leaders have been elected by this new procedure: Bruno Valkeniers was the first in 2008, followed by Gerolf Annemans in 2012 and Tom Van Grieken in 2014. Two of these three leaders were uncontested, i.e. only one candidate came forward and was elected. This is also not uncommon in other Belgian parties (Pilet \& Wauters, 2014). For the leadership selection of 2012, however, there were three candidates and eventually Gerolf Annemans won in a second voting round by only a small margin (55.4 percent against 44.6 for contender Koen Dillen, son of the founder of the party). 
It is remarkable that not only the formal procedure to select the party leader has changed (with more involvement of mid-level elites), but that at the same time also the length of tenure has decreased considerably. This leads to the suggestion that the type of leadership has changed: from an uncontested, rather authoritarian leader in line with theories about populist parties to a more inclusively selected leader (according to the assembly-based model with a large involvement of mid-level party representatives) who has to share power and who does not stay permanently in office. We should note, however, that VB remains the odd man concerning leadership selection, as all other Belgian parties (except PVDA-PTB, see below) select their party leader with more inclusive selectorates encompassing all party members in the decisive phase (plebiscitary form of intra-party democracy). This confirms the image that appeared when we analyzed in the previous section the more informal distribution of power between actors in the party. Since the resignation of the party's founder Karel Dillen in 1995, the centralization of power in the person of the president was broken in all but name. Dillen was the uncontested leader for 17 years, but his successors could not claim the same degree of authority.

In sum, a distinction can be made between two periods. The first one ranges from the foundation of the party until 2004, with leadership selection only partly in line with populist ideas: an uncontested leader is appointed by himself or by his successor without the interference of any other intermediate party actors or structures (although 'the people', or grassroots members in this case, are not involved). After 2004 and the change in name, VB had adopted a sort of representative democracy within its own ranks with large powers for the party council. This form of cascaded intra-party democracy is at odds with populist ideas about leaders who directly link people and policy.

Finally, as for the deselection of the party leader, the VB party statutes prescribe that a two-third majority of the party council can force a party leader to resign. This regulation does not differ that much from other parties, where either no procedure is provided, or a more exclusive organ such as the executive board is in charge, or a simple majority in the party council is sufficient (Pilet \& Wauters, 2014).

\section{PVDA-PTB}

In PVDA-PTB, the party leader is selected by the statutory conference, which gathers every five years (which is less frequent than for a party conference in other parties). Article 30.7 of the PVDA-PTB statutes stipulates that the statutory conference first elects a new national council, and then elects a new party president from the members of the newly elected council. The statutory conference is composed of representatives of local party sections. So here again, an assembly-based form of intra-democracy is applied: the party leader is selected by delegates, not directly by rank and file members.

Since its foundation, PVDA has had only two party leaders: Ludo Martens from 1978 until 2008, and Peter Mertens from 2008 until now. Although the procedure to select the party leader provides opportunities for power sharing (given the input of delegates of local party sections), the length of tenure of party leadership (which is extremely long) suggests that once in power, party leaders dominate the party for a long period of time. Also, the only time (in 2008) when a new party leader was selected in PVDA-PTB since its foundation, no other contenders were present. 
This seems to suggest that this party has a strong, uncontested leader, as we can expect of populist parties. Indeed, "the decision of who becomes party president is made by a very small circle" (Delwit, 2014, p. 273, own translation). The formal selection procedure by a delegation of local sections is, however, puzzling in this perspective, as well as the competence of the national council to remove the party leader from office. So, at least some checks and balances are present in this process.

In sum, party leaders in VB and PVDA-PTB are, in contrast to the populist rhetoric, neither directly elected by the population, nor by the rank and file members. Both parties use indirect selection methods with the involvement of middle-level delegates (assembly-based intra-democracy), whereas all other Belgian parties give their party members a direct say in the election of the party leader (plebiscitary intra-democracy). This is at odds with our expectations: the model of direct democracy and direct linkage between 'the people' and policy-making that populist parties favour for the political system as a whole, is not applied to the own party organization. Once in office, however, leaders of these populist parties remain much longer in power than the average leader of other parties, which strengthens their position.

\section{Career patterns of party leaders}

Before starting the analysis of the career patterns, we should note that up to now neither of these two parties has ever participated in national or regional governments (and even only in a handful local governments). This means that becoming minister, which is in many parties the logical next step after party leadership (Dumont, Fiers, \& Dandoy, 2008), is not a career option in these parties. Instead, we will discuss the parliamentary experience and the age of the party leaders when starting office and the development of their political career during and after their mandate as party leader.

\section{$V B$}

When entering office, VB party leaders are, contrary to leaders of other parties of whom only 14 per cent had no prior parliamentary experience (Pilet \& Wauters, 2014), in general rather inexperienced. Karel Dillen had no prior parliamentary experience at all when he became party leader, Frank Van Hecke had served only 2 years in the (less mediatized) European parliament, and Tom Van Grieken and Bruno Valkeniers had only a few months experience in respectively the regional Flemish parliament and the federal House when they were selected as party leader. The exception is presented by Gerolf Annemans, who was the party leader of VB between 2012 (after a heavy electoral defeat at the local elections) and 2014 (suffering a new electoral defeat at the national, regional and European elections). He had to act as a sort of crisis manager in between these two electoral defeats: he had to guarantee the continuity in the party and pave the way for a new generation of young politicians. Therefore, it was important to have an experienced person at the party's helm. When entering party leadership in 2012, Annemans already had had a long uninterrupted parliamentary career of more than 20 years.

Annemans is clearly the exception to the rule in VB where rather inexperienced leaders seem to be preferred. The limited number of parliamentary seats of VB (compared to more 
established parties) is certainly an explanation: the pool of MPs to recruit a leader from is smaller, and a logical consequence is that it is therefore interesting to look beyond this pool when selecting the party leader (or to take also novice parliamentarians into account). Another explanation could be that a new and fresh face not involved in day-to-day (parliamentary) politics is attractive for a populist party such as VB. By not being part of the mistrusted political and parliamentary elite, the party and its leader stress their anti-elitist stances.

In terms of age, VB had two party leaders that are younger than the average party leader in Belgium, which is 46.5 years old (Pilet \& Wauters, 2014). These are Frank Van Hecke, who was 37 years old when starting as party leader and Tom Van Grieken who, at 28 years, was the youngest party leader ever in Belgium. But at the same time, the three other VB party leaders were much older than average: Karel Dillen and Bruno Valkeniers were 53 years old, while Gerolf Annemans was 54 years old. So, in terms of age, it is not easy to draw general conclusions apart from the observation that the picture is mixed.

When taking into account what happens in career terms once a party leader gains office, we can conclude that this mostly constitutes the start of long political career in parliament. Karel Dillen gained a seat in the House of Representatives one year after the foundation of the party (1978). Although he switched to the Senate (in 1987) and to the European Parliament (in 1989), he stayed uninterruptedly in a parliament until 2003, which is more than 25 years in total. The same goes for Frank Van Hecke, who only had 2 years of parliamentary experience when becoming party leader: he also built up an uninterrupted parliamentary career of 20 years (mainly in the European parliament, apart from a short period of 1 year in the Senate). The inexperienced Bruno Valkeniers also enjoyed a career of 7 years in the House, which came to an end due to the electoral defeat of the party at the 2014 elections. For the current party leader, Tom Van Grieken, it is still too early to judge the development of his career.

Taken together, the general pattern in VB is that party leadership leads to a political career, rather than that someone with an already successful parliamentary career is awarded with the post of party leader. We also observe in all the cases that a parliamentary career does not immediately come to an end when resigning as party leader. For instance, Karel Dillen and Frank Van Hecke were re-elected to the European parliament when they were no longer party leader.

\section{$P V D A-P T B$}

As PVDA-PTB obtained its first parliamentary seats ever only in 2014, it does not make much sense to discuss the parliamentary experience of both party leaders. Evidently, party leaders have had no experience in parliament. This is a logical consequence of not having any seats, rather than the result of a deliberate choice based on populist considerations. It is, however, striking that the two PVDA-PTB party leaders were much younger than the average of 46.5 years when they entered office. Ludo Martens was 33 years old, and Peter Mertens 38 years. This launch of new, unspoiled and young figures could be seen as an effort to strengthen the link with the people and to make a clear distinction with the existing political elite. However, especially for age, this can have only a temporary effect, as young party leaders (like all human beings) tend to grow old. Ludo Martens was 62 years old when he resigned as party leader, being a rather old party leader on average. 
Neither Ludo Martens nor Peter Mertens succeeded in winning a parliamentary seat until now. As indicated before, PVDA-PTB only had 2 parliamentary seats in the House in its history and due to the higher popularity of the party on the francophone side of the country, they all went to French-speaking politicians, although both party leaders are Dutch-speaking (Flemish). So, the fact that party leaders did not yet enter parliament is due to the uneven geographical spread of the party's popularity rather than to a choice out of populist concerns.

All in all, few populist motives can be observed behind the profiles of the party leaders of VB and PVDA-PTB. The only element that points in the populist direction is that both parties have had party leaders that clearly differ from the average party leader in terms of experience and age, stressing their difference with established political elites. Whereas VB has mainly selected inexperienced (rather than young) party leaders, PVDA-PTB's leaders were also much younger than average. This fits into the idea to distance themselves from the existing elites of all other parties. At the same time, however, it might also be a choice out of necessity: in parties with fewer parliamentary seats than average, it is not so incomprehensible to look beyond the small pool of experienced MPs when selecting a leader.

\section{Electoral performances of party leaders}

We now analyze the electoral performances of the party leaders and their centrality in the election campaign. In particular, we take four variables into account: whether or not the party leader was a candidate for the most important national elections, i.e. for the House of Representatives; how the party leader scored in terms of preference votes; whether or not he was elected; and what role he played in the election campaign (on television).

\section{$V B$}

Rather remarkably, out of a total number of 11 elections since VB's origin, in only 6 of them was the party leader a candidate for the House. On the other occasions, the party leader was a candidate for the European Parliament (Annemans in 2014) or for the Senate (Dillen in 1987) whose elections were held on the same day, but both assemblies are generally considered to be of secondary importance (Marsh, 1998; Reif \& Schmitt, 1980). It also happened that the party leader was not a candidate at all because he had already a seat in another parliament (Dillen was no candidate for the House in 1991 and 1995 since he was already an MEP).

When the party leader was a candidate in elections, his score in terms of preference votes was not extraordinary in comparison with fellow partisans. We should explain first that in Belgium, a voter has the choice between either casting a vote for the party as a whole (list vote) or one or more votes for individual candidates (preference votes). The share of voters that cast a preference vote is generally considered to be a good indicator for the personalization of voting behavior (Wauters, Thijssen, Van Aelst, \& Pilet, 2018). Evolutions in this percentage are driven by two types of personalization: centralized (according to which the party leader becomes more important) and decentralized (which states that candidates in general become more important) (Balmas, Rahat, Sheafer, \& Shenhav, 2014). Figure 1 shows the evolution over time in the use of preference voting. For all par- 
ties together, we see an upward trend until 2003, followed by a downward trend caused by centralized personalization (which implies an increase in preference voting when the party leader is present on the list, but an increase in list votes when the party leader is not a candidate in a particular electoral district). What is of interest here is the use of preference votes by VB voters. Figure 1 clearly shows that the VB percentage has always been much lower than the general average for all parties. We see that the trend lines of both percentages follow the same trends, although in recent years the gap between VB and the general average has become smaller. Whereas at the end of the 1970s, this gap was about 20 percent points, in the last national elections it was still only about 8 percent points.

Figure 1. Percentage of voters that cast a preference vote, for all parties and for VB (House of Representatives, 1978-2019)

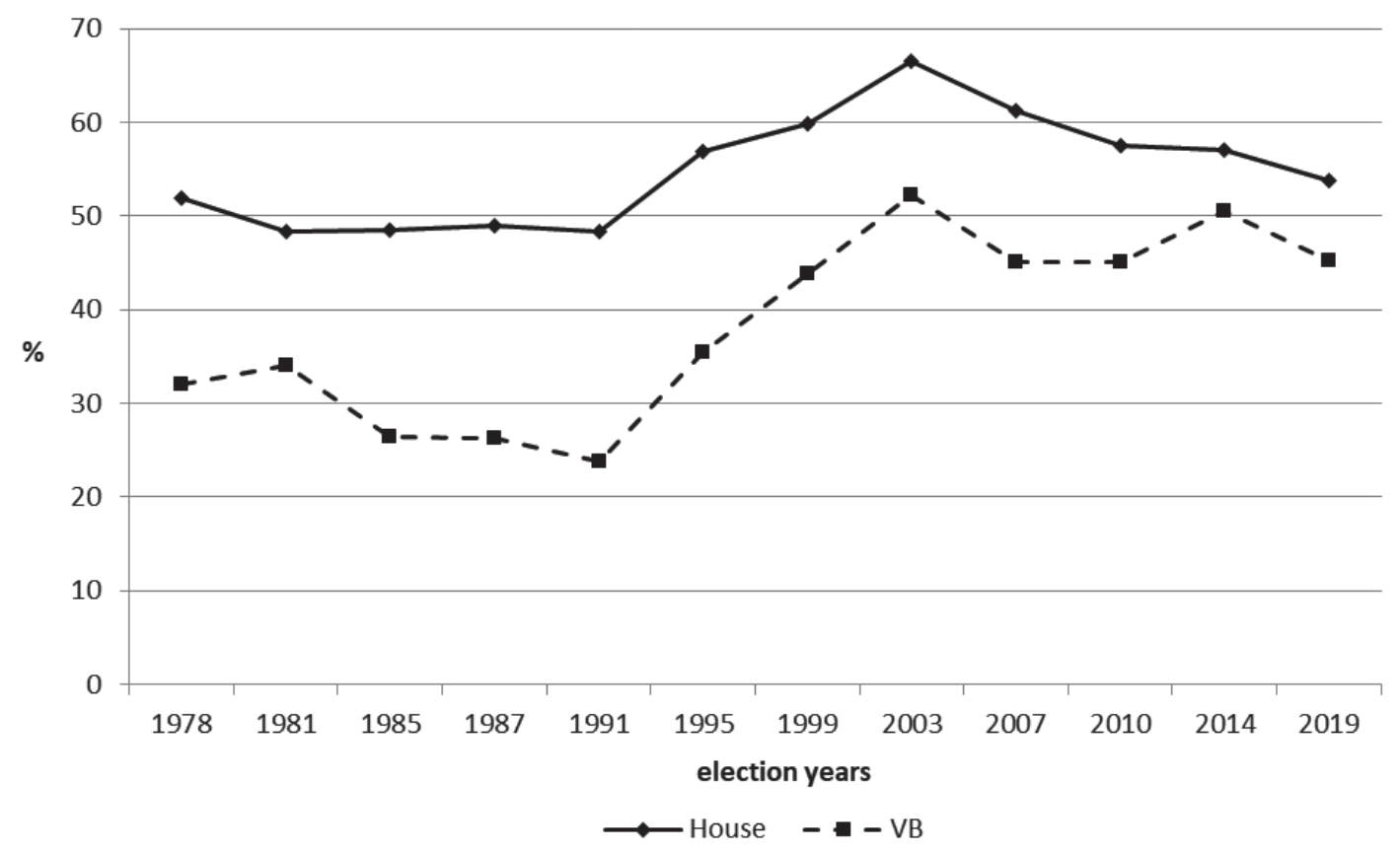

Source: own data and series in journal Res Publica on the use of preference voting, e.g. Wauters and Weekers (2008)

We can nevertheless conclude that VB in comparison to other parties is not a very personalized party when it comes to preference voting. This also becomes apparent when we analyze the number of preference votes a VB party leader is able to attract. It is not so easy to compare numbers of preference votes in Belgium, as the electoral districts are not equal in size. Therefore, rather than looking at the absolute number of preference votes, for the most part the percentage of preference votes divided by the total amount of votes for the party is taken as an indicator (the so-called degree of personalization). It has happened several times that the VB party leader was not the highest scoring candidate for his party. In 2010, for instance, party leader Bruno Valkeniers (who was only on the $3^{\text {rd }}$ list position in the Antwerp district) obtained $8.1 \%$ of the party votes while the head of the list for VB in Antwerp Gerolf Annemans attracted 31.8\% of the party votes. Also in 1999, Frank Van Hecke (32.3\% in the district of Bruges) did worse than Annemans (36.1\% in Antwerp). 
Nevertheless, every time a VB party leader was a candidate for the House (7 times), he was elected, except for Frank Van Hecke in 1999 (who was not elected to the House but obtained a seat for the European parliament which was elected on the same day).

In order to evaluate the party leader's role in the electoral campaign, we identified the person who participated for his party in the final television debate at the end of the electoral campaign (Wauters et al., 2018). We restricted our analysis to the public television chain for the national elections of 2003, 2007, 2010 and 2014 in Flanders. ${ }^{2}$ It turns out that in only 6 out of 23 cases - taking into account all of the parties that participated in the debates - the electoral leader was not the party chairman. Most of these deviant cases apply to governing parties, as it was the leader of the government (national or regional prime minister) who participated instead. Yet also for VB it happened twice (in 2007 and 2010) that not the party chairman, but the leader of the (Flemish) parliamentary party, Filip Dewinter, participated to this debate. This is rather remarkable for an opposition party and particularly undermines the idea of one, single charismatic leader.

\section{$P V D A-P T B$}

Analyzing the same indicators for PVDA-PTB, one comes to a similar conclusion. Also here, the party leader did not always figure on the candidate lists for the House: only in 7 out of 11 elections was the party leader a candidate. Especially, Ludo Martens was no longer a candidate once he was in the party leadership office for some time: he was not a candidate for the House in 1995, 1999, 2003 and 2007.

Also in terms of electoral performance, PVDA-PTB party leaders did not outperform other candidates of the party. Here again, Ludo Martens' electoral scores were modest, literally attracting only a few dozens of votes in the Brussels district in the 1980s. The new party leader, Peter Mertens, has been present on the ballot on all recent occasions since he came to power and has also been more successful. In 2010, he was head of list in the district of Antwerp and attracted 17.9\% of the party votes, and in 2014 he attracted, from the same position, 26,010 preference votes (or 50.4\% of party votes). In 2019 , he further increased his score by obtaining 46,802 preference votes, which was $74.5 \%$ of the party votes in his district, and finally got elected. These scores are in sharp contrast with the modest scores of Ludo Martens. Peter Mertens also performs much better than most other (even elected) candidates from the party. He was only trumped in relative terms by his co-partisan and the party's figurehead in the Walloon Region, Raoul Hedebouw, who achieved in his own electoral district $83.3 \%$ of party votes in the 2019 elections. Despite this increasing concentration of preference votes for Mertens at the last elections, he only succeeded in being elected in 2019 (becoming the first PVDA-PTB party leader elected in parliament).

As for the centrality of the party leader in the electoral campaign, we can be short, as PVDA-PTB has up to now never been invited for the final television debate by the public broadcaster in Flanders. This does not mean that the most recent party leader Peter Mertens did not play a central role in the party's recent electoral campaigns. For instance

2 Only at the 2007 elections, there was no general final debate on the public television in Flanders. Alternatively, we take (only for these elections) the general debate which was broadcast by commercial television. For other election years, final debate was not always held by the commercial broadcaster, which renders them not suitable for an analysis over time. 
in 2014, a personalized campaign entitled 'vote Peter Mertens into parliament' was set up in Antwerp, one of the largest electoral districts of the country. At the same time, however, the same slogan was used in other electoral districts with the names of other heads of list in that district.

\section{Conclusions}

In this article, we have analyzed to what extent the two Belgian populist parties (VB and PVDA-PTB) apply their populist ideas to their own party organization, and to the position of the party leader in particular. If populist parties would indeed mirror their populist ideas, we should expect to have the party leader directly elected by the rank and file members, with (formal) powers and authority concentrated in his/her office, unhindered by checks and balances imposed by intermediary actors, and playing a dominant role in the party's electoral campaign strategies and electoral successes.

Our analysis reveals that only a few of these features can be found for party leaders in VB and PVDA-PTB. Indeed, these party leaders have few institutional counterbalancing powers within the party, and this to a larger extent than in most other parties. In VB, the party statutory rules grant the leader much greater formal powers than in other parties, while the PVDA-PTB remains vague in its statutory rules leaving much opportunity for the party leader to fill in his own powers to the maximum. Another aspect in line with strong leadership advocated by populists, is the duration of the mandate of party leader. For PVDA-PTB and for VB (until recently), the party leader stays much longer in office than average, with both parties having leaders who have served for about 20 years. Finally, the profile of young and/or inexperienced party leaders in both parties corresponds to the populist idea of distinguishing themselves from the existing (parliamentary) elite, although age and experience are only temporary features of party leaders.

There are also, however, clear counter-indications. For one, both VB and PVDA-PTB leaders in reality have to share power with other highly influential persons within the party. Additional counter-indications are most prominent for the selection process. According to populist ideas, we would expect a plebiscitary model of intra-party democracy with a direct link between the grassroots and the party leader without much inference from intermediary party actors. In fact, we find an opposite pattern: whereas all other Belgian parties select their party leader by elections in which all members can vote, both VB and PVDA-PTB use an assembly-based model of intra-party democracy in which delegates of party sections can decide (either in the party council or the national council). The involvement of an intermediate level between leader and followers, characteristic for representative democracy, is often criticized by populists, but is nevertheless applied in their own internal functioning.

A second aspect where practice does not correspond to our expectations is the role of the party leader in elections. In both parties, the leader has never been the party's (sole) spearhead in the election campaign nor has the party leader attracted the lion's share of preference votes for his party. On the contrary, it happened regularly that party leaders of VB and PVDA-PTB were not a candidate for (the most important) elections (those of the House), and even when they were, they often were trumped by fellow partisans in their electoral score. 
All in all, Belgian populist parties only mirror their populist ideals to a limited extent in the position and role of the party leader. Although we find some traces of these ideals (in the profiles of the party leaders, the duration of their mandate and their formal powers) that distinguish these parties from others, there are other aspects in which these populist parties are similar to other parties (informal power distribution, and role of leaders in elections) or even adopt a less 'populist' practice (leadership selection).

When considering evolution over time, there are indications in contradictory directions. In the early years of these parties, there was a strong and uncontested leader not selected by (and not accountable to) intermediary actors and with more discretionary power at his disposal than now, while in recent years populist party leaders start to play a more central role in the election campaign. The latter phenomenon might be due to general processes such as personalization rather than to specific populist beliefs, as this can also be found in other parties. In sum, the role of leaders in a party organization is influenced by several factors (including path-dependency and contagion effects from other parties), and not only by party ideology.

Although providing and testing additional explanations for these findings are beyond the scope of this article, one can nonetheless speculate on some tentative explanations based on the nature of populism. For one, perhaps VB and PVDA-PTB want to be different from the established parties in Belgium, who all select their party leaders directly in a member vote. As this direct member vote is a typical feature of Belgian parties, the reaction of populist parties in Belgium (i.e. not electing their party leader directly) could be a way for them to stress that they are not a typical party. This might also explain why the Belgian case is different from populist parties in other countries.

Another, and an arguably more convincing argument could also be that populism is simply too thin of an ideology to provide compelling instructions for how to organize a party. Regardless of populist tendencies within the party, it would then be the fuller ideology that provides guidelines for how to organize the party. This is particularly visible in the case of PVDA-PTB, which was founded as a communist-Marxist party before the rise of modern populism. Consequently, their organization based on various sections within the party is typical of a communist party, which overrules the organizational ideas of populism. One could make a similar argument about VB, which is primarily a radical right nationalist party. This could, lead us to speculate about the nature of populism as a political family. Our findings would suggest that, if one assumes that ideological families provide important organizational guidelines, populist parties do not, in fact, form a political family. Future research might delve deeper into this fundamental question and ask (again) whether populism is an ideology at all, or "merely" a political style.

\section{References}

Akkerman, A., Mudde, C., \& Zaslove, A. (2013). How Populist Are the People? Measuring Populist Attitudes in Voters. Comparative Political Studies, 47(9), 1324-1353. doi:10.1177/0010414013512600

Balmas, M., Rahat, G., Sheafer, T., \& Shenhav, S. R. (2014). Two routes to personalized politics: Centralized and decentralized personalization. Party Politics, 20(1), 37-51. doi:10.1177/1354068811436037 
Barr, C., Clarke, S., \& Lewis, P. (2018, 12/12/2018). Measuring Populism: How The Guardian Charted Its Rise. The Guardian. Retrieved from https://www.theguardian.com/ world/2018/nov/20/measuring-populism-how-guardian-charted-rise-methodology

Canovan, M. (1999). Trust the People! Populism and the Two Faces of Democracy. Political Studies, 47(1), 2-16.

Carter, E. (2018). Right-Wing Extremism/Radicalism: Reconstructing the Concept. Journal of Political Ideologies, 23(2), 157-182. doi:10.1080/13569317.2018.1451227

Chiru, M., Gauja, A., Gherghina, S., \& Rodriguez-Teruel, J. (2015). Explaining change in party leadership selection rules. In W. Cross \& J.-B. Pilet (Eds.), The politics of party leadership: A cross national perspective (pp. 31-49). Oxford: Oxford University Press.

Close, C. (2018). Parliamentary party loyalty and party family: The missing link? Party Politics, 24(2), 209-219. doi:10.1177/1354068816655562

de Lange, S. L., \& Art, D. (2011). Fortuyn versus Wilders: An Agency-Based Approach to Radical Right Party Building. West European Politics, 34(6), 1129-1149.

de Lange, S. L., \& Mügge, L. M. (2015). Gender and right-wing populism in the Low Countries: ideological variations across parties and time. Patterns of Prejudice, 49(1-2), 6180. doi:10.1080/0031322X.2015.1014199

de Vet, B. P. S., \& Wauters, B. P. S. (2018). Follow the leader: testing a deductive approach for studying parliamentary party leadership roles. In: 2018.

de Vreese, C., Esser, F., Aalberg, T., Reinemann, C., \& Stanyer, J. (2018). Populism as an Expression of Political Communication Content and Style: A New Perspective. International Journal of Press/Politics, 23(4), 423-438.

De Winter, L., \& Dumont, P. (2000). PPGs in Belgium: subjects of partitocratic dominion. In K. Heidar \& R. Koole (Eds.), Parliamentary party groups in European democracies. Political parties behind closed doors. (pp. 106-129). London: Routlegde.

Delwit, P. (2014), PTB: nouvelle gauche, vieille recette. Brussel: Pire.

Deschouwer, K. (2009). The politics of Belgium: governing a divided society. Basingstoke: Palgrave Macmillan.

Dewachter, W. (2005). Inleiding. Het partijbureau in het kluwen van de particratie. In Een half eeuw partijbureau in België (pp. 6-30). Leuven: Acco.

Dewachter, W. (2014). De trukendoos van de Belgische particratie: een Europese schande. Kalmthout: Pelckmans.

Dumont, P., Fiers, S., \& Dandoy, R. (2008). Ups and downs of ministerial careers in a partitocratic federal state. In K. Dowding \& P. Dumont (Eds.), The Selection of Ministers in Europe: Hiring and Firing (pp. 125-146). London: Routledge.

Enyedi, Z., \& Linek, L. (2008). Searching for the right organization: ideology and party structure in East-Central Europe. Party Politics, 14 (4), 455-477.

Hazan, R. Y., \& Rahat, G. (2010). Democracy within parties: candidate selection methods and their political consequences. Oxford: Oxford University Press.

Heinisch, R. (2003). Success in opposition. Failure in government. Explaining the performance of right-wing populist parties in public office. West European Politics, 26 (3), 91-113.

Heinisch, R., \& Mazzoleni, O. (Eds.). (2016). Understanding Populist Party Organisation: The Radical Right in Western Europe. London: Palgrave Macmillan.

Jagers, J. (2002). Eigen democratie eerst! Een comparatief onderzoek naar het intern democratisch gehalte van de Vlaamse politieke partijen. RES PUBLICA, 44 (1), 73-96. 
Jagers, J., \& Walgrave, S. (2007). Populism as Political Communication Style: An Empirical Study of Political Parties' Discourse in Belgium. European Journal of Political Research, 46, 319-345. doi:10.1111/j.1475-6765.2006.00690.x

Jones, E. (2007). Populism in Europe. SAIS Review of International Affairs, 27 (1), 37-47. doi:10.1353/sais.2007.0010

Karvonen, L. (2010). The personalisation of politics: a study of parliamentary democracies. Colchester: Ecpr Press.

Marsh, M. (1998). Testing the Second-Order Election Model after Four European Elections. British Journal of Political Science, 28, 591-607.

McDonnell, D. (2015). Populist Leaders and Coterie Charisma. Political Studies, 64 (3), 719-733. doi:10.1111/1467-9248.12195

McDonnell, D. (2017). Populist Leadership. Social Alternatives, 36 (3), 26-30.

Moffitt, B., \& Tormey, S. (2013). Rethinking Populism: Politics, Mediatisation and Political Style. Political Studies, 62 (2), 381-397. doi:10.1111/1467-9248.12032

Mudde, C. (2004). The Populist Zeitgeist. Government and Opposition, 39 (4), 541-563.

Mudde, C. (2007). Populist radical right parties in Europe. Cambridge: Cambridge University Press.

Mudde, C. (2008). The Populist Radical Right: A Pathological Normalcy. Willy Brandt Series of Working Papers in International Migration and Ethnic Relations, 3 (07), 1-19.

Mudde, C. (2013). Three Decades of Populist Radical Right Parties in Western Europe: So What? European Journal of Political Research, 52 (1), 1-19. doi:10.1111/j.14756765.2012.02065.x

Mudde, C. (2014). Fighting the System? Populist Radical Right Parties and Party System Change. Party Politics, 20 (2), 217-226.

Norris, P., \& Inglehart, R. (2019). Cultural Backlash: Trump, Brexit and Authoritarian Populism. Cambridge: Cambridge University Press.

Pauwels, T. (2011a). Measuring Populism: A Quantitative Text Analysis of Party Literature in Belgium. Journal of Elections, Public Opinion and Parties, 21(1), 97-119. doi:10.1080/ 17457289.2011.539483

Pauwels, T. (2011b). Populisme in Vlaanderen. Samenleving en Politiek, 18(7), 4-15.

Pauwels, T. (2015). Populism in Western Europe: Comparing Belgium, Germany and The Netherlands. London: Routledge.

Pilet, J.-B., \& Cross, W. (2018). Dataset Comparative Study of Party Leaders (COSPAL).

Pilet, J.-B., \& Wauters, B. (2014). The selection of party leaders in Belgium. In J.-B. Pilet \& W. Cross (Eds.), The Selection of Political Party Leaders in Contemporary Parliamentary Democracies. A Comparative Study (pp. 30-46). London: Routledge.

Poguntke, T., Scarrow, S., \& Webb, P. (2016). Party Rules, Party Resources and the Politics of Parliamentary Democracies: How Parties Organize in the 21st Century. Party Politics, 22 (7), 1-18.

Rahat, G., \& Hazan, R. Y. (2001). Candidate selection methods an analytical framework. Party Politics, 7 (3), 297-322.

Reif, K., \& Schmitt, H. (1980). Nine Second-Order National Elections-A Conceptual Framework for the Analysis of European Election Results. European Journal of Political Research, 8 (1), 3-44.

Rooduijn, M., \& Akkerman, T. (2015). Flank Attacks: Populism and Left-Rigth Radicalism in Western Europe. Party Politics, 23 (3), 193-204. doi:10.1177/1354068815596514 
Rooduijn, M., de Lange, S. L., \& van der Brug, W. (2012). A Populist Zeitgeist? Programmatic Contagion by Populist Parties in Western Europe. Party Politics, 20 (4), 563-575. doi:10.1177/1354068811436065

Rooduijn, M., \& Pauwels, T. (2011). Measuring Populism: Comparing Two Methods of Content Analysis. West European Politics, 34 (6), 1272-1283. doi:10.1080/01402382.20 11.616665

Taggart, P. (1998). A Touchstone of Dissent: Euroscepticism in Contemporary Western European Party Systems. European Journal of Political Research, 33, 363-388.

Taggart, P. (2000). Populism. Buckingham: Open University Press.

Van Haute, E., \& Pauwels, T. (2016). The Vlaams Belang: Party Organization and Party Dynamics. In R. Heinisch \& O. Mazzoleni (Eds.), Understanding Populist Party Organisation: The Radical Right in Western Europe (pp. 49-78). London: Palgrave Macmillan.

Van Haute, E., Pauwels, T., \& Sinardet, D. (2018). Sub-State Nationalism and Populism: The Cases of Vlaams Belang, Nex Flemish Alliance and DéFi in Belgium. Comparative European Politics, 16, 954-975. doi:10.1057/s41295-018-0144-Z

Viviani, L. (2017). A Political Sociology of Populism and Leadership. Società Mutamento Politica, 8 (15), 279-303. doi:10.13128/SMP-20860

Wauters, B. (2014). Democratising party leadership selection in Belgium: motivations and decision-makers. Political Studies, 61 (1), 61-80.

Wauters, B., Thijssen, P., Van Aelst, P., \& Pilet, J.-B. (2018). Centralized personalization at the expense of decentralized personalization. The decline of preferential voting in Belgium (2003-2014). Party Politics, 24 (5), 511-523. doi:https://doi. org/10.1177/1354068816678882

Wauters, B., \& Weekers, K. (2008). Het gebruik van de voorkeurstem bij de federale parlementsverkiezingen van 10 juni 2007. RES PUBLICA, 50 (2), 49-88.

Webb, P. (2013). Who is willing to participate? Dissatisfied democrats, stealth democrats and populists in the United Kingdom. European Journal of Political Research, 52 (6), 747-772.

Weyland, K. (2001). Clarifying a Contested Concept: Populism in the Study of Latin American Politics. Comparative Politics, 34 (1), 1-22.

Wiles, P. (1969). A Syndrome, not a Doctrine: Some Elementary Eheses on Populism. In G. Ionescu \& E. Gellner (Eds.), Populism: Its Meaning and National Characteristics. London: Weidenfeld and Nicolson.

Zaslove, A. (2008). Here to Stay? Populism as a New Party Type. European Review, 16 (3), 319-336. 